\title{
Progress of antibody-based inhibitors of the HGF-CMET axis in cancer therapy
}

\author{
Ki-Hyun $\mathrm{Kim}^{1,2}$ and Hyori $\mathrm{Kim}^{3}$ \\ Dysregulated receptor tyrosine kinase signaling in human cancer cells leads to tumor progression, invasion and metastasis. The \\ receptor tyrosine kinase cMET is frequently overexpressed in cancer tissue, and activation of cMET signaling is related to drug \\ resistance and the processes of carcinogenesis, invasion and metastasis. For that reason, cMET and its ligand, hepatocyte \\ growth factor (HGF), are considered prime targets for the development of anticancer drugs. At least eight anti-cMET and four \\ anti-HGF antibodies have been tested or are being tested in clinical trials. However, to date none of these HGF/cMET inhibitors \\ have shown significant efficacy in clinical trials. Furthermore, no receptor tyrosine kinase inhibitors primarily targeting cMET \\ have been approved. Given that neutralization of HGF or cMET does not cause significant adverse effects, inhibition of the \\ HGF/CMET signaling pathway appears to be safe. In this review, we summarized the completed and ongoing clinical trials testing \\ antibody- or protein-based anticancer drugs targeting cMET and HGF.
}

Experimental \& Molecular Medicine (2017) 49, e307; doi:10.1038/emm.2017.17; published online 24 March 2017

\section{INTRODUCTION}

The receptor tyrosine kinase cMET and its only known ligand, hepatocyte growth factor (HGF), play crucial roles in cellular proliferation, survival, invasion, tissue development and organ regeneration. cMET is produced as a single-chain precursor and converted by post-translational modification to form a structure that is linked by disulfide bonds. Mature cMET consists of a $50-\mathrm{kDa}$ extracellular $\alpha$-chain and a $140-\mathrm{kDa}$ transmembrane $\beta$-chain. ${ }^{1}$ HGF is secreted as an inactive precursor (pro-HGF) that is activated through cleavage by serine proteases. Consequently, the active ligand structure of HGF consists of an N-terminal domain and Kringle domains $(\mathrm{K} 1-\mathrm{K} 4)$ in the $\alpha$-chain and a serine protease-like domain in the $\beta$-chain. ${ }^{2}$ The $\mathrm{N}$-terminal domain and the $\mathrm{K} 1$ mediate high-affinity binding to cMET, which appears to induce the formation of a secondary binding site within the HGF $\beta$-chain. With this subsequent binding to cMET, HGF forms a strong complex that can induce signal transduction. ${ }^{3}$ The binding of active HGF to cMET leads to receptor multimerization and internalization, multiple phosphorylation of tyrosine residues in the intracellular kinase domain and subsequent activation of numerous signaling cascades related to cancer progression, invasion and metastasis. ${ }^{4}$
Despite tight regulation of HGF-induced cMET activation, dysregulated HGF-cMET signaling is observed in multiple malignant neoplasms. ${ }^{5}$ Aberrant cMET activation can occur through HGF-independent mechanisms such as MET mutations, gene amplification and transcriptional upregulation. ${ }^{6}$ cMET is overexpressed in a number of solid tumors, including brain cancer, breast cancer, colorectal cancer, gastric cancer, head and neck cancer, lung cancer, liver cancer, skin cancer, prostate cancer and soft tissue cancers. ${ }^{4,7,8}$ cMET can also be activated by interaction with epidermal growth factor receptor (EGFR). Given the resistance to EGFR tyrosine kinase inhibitors in cMET-expressing lung cancer and the synergistic effect of cMET and EGFR inhibitors, dual targeting of EGFR and cMET is a promising therapeutic strategy. ${ }^{9-11}$

Elevated tumor and plasma HGF levels are also observed in patients with certain types of cancer such as invasive breast carcinoma, glioma, multiple myeloma and sarcomas. ${ }^{12-15}$ Several in vivo studies have shown that activation of the HGF-cMET signaling pathway triggers cancer invasion and metastasis. ${ }^{16-19}$ Thus, multiple therapeutic agents that target the HGF-cMET pathway in various cancers are under development. For example, several monoclonal antibodies (mAbs) inhibit the HGF-cMET axis by blocking the binding of HGF to cMET or by targeting cMET on the cell surface. The safety

\footnotetext{
${ }^{1}$ Cancer Research Institute, College of Medicine, Seoul National University, Jongno-gu, Seoul, Republic of Korea; ${ }^{2}$ Department of Biochemistry and Molecular Biology, College of Medicine, Seoul National University, Jongno-gu, Seoul, Republic of Korea and ${ }^{3}$ Institute for Life Sciences, ASAN Medical Center, Songpa-gu, Seoul, Republic of Korea

Correspondence: Dr H Kim, Institute for Life Sciences, ASAN Medical Center, 88, Olympic-ro, Songpa-gu, Seoul 05505, Republic of Korea.

E-mail: hyorikim@amc.seoul.kr or hyol409@gmail.com

Received 8 December 2016; accepted 22 December 2016
} 
Table 1 Antibodies targeting the HGF-cMET axis in development

\begin{tabular}{|c|c|c|c|c|c|}
\hline Drug name & Developer & Format & Indication & $\begin{array}{l}\text { Clinical trial } \\
\text { status }\end{array}$ & $\begin{array}{l}\text { Clinical trial } \\
\text { identifier }\end{array}$ \\
\hline \multicolumn{6}{|l|}{ Anti-HGF antibodies } \\
\hline $\begin{array}{l}\text { Rilotumumab } \\
\text { (AMG-102) }\end{array}$ & Amgen & mAb (IgG2) & $\begin{array}{l}\text { Colorectal cancer, Renal cell } \\
\text { carcinoma, Glioma, Gastric } \\
\text { cancer, Esophageal cancer }\end{array}$ & $\begin{array}{l}\text { Phase II, } \\
\text { Phase III }\end{array}$ & $\begin{array}{l}\text { NCT00770848 } \\
\text { NCT00422019 } \\
\text { NCT00427440 } \\
\text { NCT02137343 } \\
\text { NCT01697072 } \\
\text { NCT02926638 } \\
\text { NCTO0719550 }\end{array}$ \\
\hline $\begin{array}{l}\text { Ficlatuzumab } \\
\text { (AV-299, SCH900105) }\end{array}$ & $\begin{array}{l}\text { AVEO Pharmaceuticals, } \\
\text { Inc./Biodesix Inc. }\end{array}$ & mAb (IgG1) & Non-small cell lung cancer & Phase II & $\begin{array}{l}\text { NCT02318368 } \\
\text { NCT01039948 }\end{array}$ \\
\hline \multicolumn{6}{|l|}{ Anti-cMET antibodies } \\
\hline SAIT301 & $\begin{array}{l}\text { Young Suk Park/Samsung } \\
\text { Medical Center }\end{array}$ & $\mathrm{mAb}$ & Solid tumors & Phase I, active & NCT02296879 \\
\hline ARGX-111 & arGEN-X BVBA & $\mathrm{mAb}$ & c-MET-overexpressing cancer & Phase I, active & NCT02055066 \\
\hline $\begin{array}{l}\text { Onartuzumab (MetMAb, } \\
\text { R05490258) }\end{array}$ & $\begin{array}{l}\text { Genentech, } \\
\text { Inc./Hoffmann-La Roche }\end{array}$ & mAb (IgG1) & $\begin{array}{l}\text { Glioblastoma, Non-small cell } \\
\text { lung cancer, Gastric cancer, } \\
\text { Breast cancer, Colorectal cancer }\end{array}$ & $\begin{array}{l}\text { Phase II, } \\
\text { Phase III }\end{array}$ & $\begin{array}{l}\text { NCT01632228 } \\
\text { NCT01456325 } \\
\text { NCT02031744 } \\
\text { NCT01887886 } \\
\text { NCT01662869 } \\
\text { NCT02488330 } \\
\text { NCT01186991 } \\
\text { NCT01418222 }\end{array}$ \\
\hline JNJ-61186372 & $\begin{array}{l}\text { Janssen Research } \\
\text { \& Development, LLC }\end{array}$ & bsAb (DuoBody) & Non-small cell lung cancer & Phase I, active & NCT02609776 \\
\hline DN30 & $\begin{array}{l}\text { Metheresis Translational } \\
\text { Research S.A. }\end{array}$ & Fab & & Investigational & \\
\hline LY3164530 & Eli Lilly \& Company & bsAb & Neoplasms & Phase I & NCT02221882 \\
\hline \multicolumn{6}{|c|}{ Antibody mimetic engineered protein } \\
\hline MP0250 & Molecular Partners AG & $\begin{array}{l}\text { Designed ankyrin } \\
\text { repeat protein }\end{array}$ & Advanced solid tumors & $\begin{array}{l}\text { Phase I/II, } \\
\text { active }\end{array}$ & NCT02194426 \\
\hline \multicolumn{6}{|l|}{ Competitive analog of HGF } \\
\hline Ad-NK4 & Chiba University & $\begin{array}{l}\text { Adenovirus gene } \\
\text { therapy }\end{array}$ & & Investigational & \\
\hline
\end{tabular}

Abbreviations: bsAb, bispecific antibody; Fab, antigen-binding fragment; HGF, hepatocyte growth factor; mAb, monoclonal antibody.

profiles of these agents are better than those of small chemicals because mAbs have excellent target specificity and predictable pharmacological properties. Adverse effects and dose-limiting toxicities have been reported for small-molecule inhibitors, but few dose-limiting toxicities have been reported for mAbs. ${ }^{20}$
Numerous mAbs targeting the HGF-cMET signaling pathway with different mechanisms of action have been tested recently in patients with solid tumors (Table 1). This review summarizes the features of these antibodies or related proteins targeting the HGF-cMET axis and recent clinical findings. 


\section{ANTI-CMET ANTIBODIES}

Onartuzumab (MetMAb)

Many of the cMET antagonists developed so far are bivalent (two-armed) antibodies, which induce receptor crosslinking and downstream signaling after binding to cMET. However, onartuzumab is a monovalent antibody generated with Fab fragments with murine variable heavy and light domains fused to human IgG1 constant domains. ${ }^{21}$ Onartuzumab blocks the high-affinity binding of the HGF $\alpha$-chain to cMET but not the binding of the HGF $\beta$-chain. ${ }^{22}$ Several preclinical studies have investigated the treatment efficacy of onartuzumab. In an intracranial xenograft mouse model of human glioblastoma, onartuzumab treatment decreased tumor size by $98.7 \% .^{23}$ In an orthotopic xenograft mouse model of pancreatic cancer, onartuzumab abolished tumor growth, decreased cMET phosphorylation and improved survival. ${ }^{24}$ A phase I study evaluated the safety and efficacy of single-agent onartuzumab, as well as combination treatment with onartuzumab plus bevacizumab in patients with locally advanced and metastatic solid tumors. A maximum tolerated dose was not reached, and the half-life was 11 days. In addition, no adverse pharmacokinetic interactions with bevacizumab were observed. ${ }^{25}$ In a phase II clinical study of onartuzumab in combination with erlotinib for advanced non-small cell lung cancer (NSCLC), the addition of onartuzumab to erlotinib significantly improved progression-free survival and overall survival (OS) in patients with positive immunohistochemical staining for cMET. ${ }^{26,27}$ In contrast, a phase II study of patients with predominantly cMET-negative metastatic triple-negative breast cancer found that combining onartuzumab with paclitaxel with or without bevacizumab did not provide clinical benefit. ${ }^{28}$ In addition, a randomized, double-blind, phase III study of onartuzumab plus erlotinib in patients with cMET-positive advanced NSCLC was stopped because of lack of clinical efficacy. In this study, median OS was 6.8 months for the onartuzumab plus erlotinib arm and 9.1 months for the erlotinib plus placebo arm (hazard ratio, $1.27 ; 95 \%$ confidence interval, $0.98-1.65 ; P=0.07){ }^{29}$ Further development of onartuzumab has been halted.

\section{Emibetuzumab (LY2875358)}

Emibetuzumab is a bivalent humanized anti-cMET IgG4 mAb that blocks HGF binding to cMET. Binding of emibetuzumab to cMET promotes internalization and degradation of cMET, in contrast to onartuzumab, which does not induce cMET degradation. Emibetuzumab inhibited both HGF-dependent and -independent tumor growth in mouse xenograft models. ${ }^{30}$ A recent first-in-human phase I clinical study tested singleagent emibetuzumab in patients with solid tumors and emibetuzumab in combination with erlotinib in patients with NSCLC (NCT01287546). ${ }^{31}$ No dose-limiting toxicities and adverse events were observed, and half-life was $\sim 11$ days. Of the 23 patients receiving emibetuzumab monotherapy, one patient achieved a partial response (objective response rate $=4.3 \%)$ and five patients $(21.7 \%)$ achieved stable disease. Two of the 14 NSCLC patients receiving combination treatment achieved a partial response (objective response rate $=14.3 \%)$ and four $(28.6 \%)$ achieved stable disease. Phase II clinical studies of emibetuzumab in NSCLC patients with EGFR mutations (NCT01897480) and combination treatment with the anti-VEGFR2 mAb ramucirumab (NCT02082210) are ongoing.

\section{LY3164530}

LY3164530 is a bispecific anti-EGFR/cMET antibody generated by fusing an anti-EGFR single-chain variable fragment (humanized cetuximab sequence) to the N-terminus of the emibetuzumab heavy chain. LY3164530 binds and internalizes cMET and EGFR without agonistic activity. In a NSCLC xenograft model, LY3164530 showed better antitumor efficacy than combination treatment with emibetuzumab and cetuximab. ${ }^{32}$ A phase I clinical study is ongoing (NCT02221882).

\section{JNJ-61186372}

The bispecific EGFR/cMET antibody JNJ-61186372 is a heterodimeric IgG1 composed of two units targeting EGFR and cMET. $^{33}$ The cMET-binding IgG1 molecule is generated with a K490R mutation in the $\mathrm{CH} 3$ domain and the EGFR-binding IgG1 molecule is generated with a F405L mutation in the $\mathrm{CH} 3$ domain. With these IgG1 molecules, heterodimeric IgG is produced using the controlled Fab-arm exchange method. ${ }^{34}$ JNJ-61186372 inhibits tumor cell growth by the downregulation of both EGFR and cMET in combination with enhanced antibody-dependent cell-mediated cytotoxicity. ${ }^{33,35-37}$ Patients with NSCLC with EGFR mutations are being recruited for a phase I clinical study (NCT02609776).

\section{SAIT301}

SAIT301 is a monoclonal humanized antibody that promotes Casitas B-lineage lymphoma (CBL)-independent and leucinerich repeats and immunoglobulin-like domain-containing protein 1 (LRIG1)-mediated cMET degradation. ${ }^{38}$ SAIT301 inhibits the invasion and migration of nasopharyngeal cancer cells by downregulating EGR-1 expression. ${ }^{39}$ In cMET-positive gastric cancer cell lines treated with SAIT301 in combination with paclitaxel, cMET was downregulated and poly(ADP ribose) polymerase (PARP) cleavage was enhanced compared to paclitaxel monotherapy. ${ }^{40} \mathrm{~A}$ phase I clinical study is currently recruiting patients with cMET-positive solid tumors (NCT02296879).

\section{ABT-700 (h224G11)}

ABT-700 (previously known as h224G11) is a humanized, bivalent monoclonal antibody that inhibits cMET dimerization and activation that is induced by HGF or by the high density of cMET on the cell surface (independent of ligand). ABT-700 inhibits tumor growth in mice bearing gastric and lung cancer xenografts with MET amplification. ${ }^{41}$ A phase I study of ABT-700 alone and in combination with docetaxel, 5-fluoruracil, folinic acid, irinotecan and cetuximab (FOLFIRI/cetuximab) or erlotinib is ongoing in patients with advanced solid tumors that may have MET amplification or cMET overexpression (NCT01472016). 


\section{ARGX-111}

ARGX-111 is an afucosylated IgG1 antibody characterized by improved tissue penetration and enhanced antibody-dependent cellular cytotoxicity. ${ }^{42}$ ARGX-111 inhibits ligand-dependent cMET activation and shows cytotoxic activity in both cMET-expressing human cancer cells and patient-derived chronic lymphocytic leukemia and acute myeloid leukemia cells. In an orthotopic mouse model, ARGX-111 decreased the number of circulating tumor cells and suppressed metastasis. ${ }^{43}$ This drug is currently under clinical evaluation in a phase I trial in patients with advanced cancers overexpressing cMET (NCT02055066).

\section{DN30}

DN30 is a monovalent chimeric Fab that induces the proteolytic cleavage of cMET, which causes the release of the soluble receptor and rapid proteasomal degradation of the intracellular portion. ${ }^{44}$ DN30 Fab reduces both HGF-dependent and HGF-independent tumor cell growth in vitro ${ }^{45}$ and delays tumor growth in preclinical models of human gastric cancer, lung carcinoma, and glioblastoma. However, because of its small molecular size, DN30 Fab is rapidly eliminated by the kidney. PEGylation and gene delivery have been proposed to overcome this drawback. ${ }^{46,47}$

\section{ANTI-HGF ANTIBODIES}

\section{Rilotumumab (AMG-102)}

Rilotumumab is a fully human anti-HGF IgG2 antibody that binds to the HGF $\beta$-chain, thereby inhibiting HGF-cMET binding. ${ }^{48}$ It is the first HGF inhibitor to reach phase III development. Results of a phase I trial in patients with solid tumors showed a maximum tolerated dose of $20 \mathrm{mg} \mathrm{kg}^{-1}$ every 2 weeks and a mean half-life of $15.4 \mathrm{~h}$. All adverse events (fatigue, constipation, anorexia and nausea/vomiting) were low-grade. ${ }^{49}$ A phase II study demonstrated that adding rilotumumab to epirubicin, cisplatin and capecitabine (ECX) chemotherapy extended OS and progression-free survival in MET-positive patients with gastric cancer or gastroesophageal junction adenocarcinoma. ${ }^{50}$ Based on the positive results in phase II study, two phase III clinical trials (RILOMET-1 and RILOMET-2) were initiated. The RILOMET-1 study was stopped early in November 2014 because of lack of efficacy. At the data cutoff point, 128 deaths were observed in the rilotumumab arm, and 107 deaths were observed in the placebo arm, and a significantly shorter median OS was observed in rilotumumab arm compared with the control group (median OS 9.6 months vs 11.5 months, hazard ratio: 1.37, $P=0.016$ ). No subgroup benefitted from rilotumumab treatment, including patients with higher MET expression. ${ }^{51}$

\section{Ficlatuzumab (AV-299)}

Ficlatuzumab is a humanized anti-HGF antibody. In a phase I trial, ficlatuzumab monotherapy was well tolerated in patients with solid tumors receiving 2, 5 or $10 \mathrm{mg} \mathrm{kg}^{-1}$ or the maximum dose of $20 \mathrm{mg} \mathrm{kg}^{-1}$. The most commonly observed toxicities were peripheral edema, fatigue and nausea. In this study, ficlatuzumab was administered to 37 patients with solid tumors either as a single agent (24 patients) or in combination with a daily $150 \mathrm{mg}$ dose of erlotinib (13 patients). The best overall response (monotherapy or combination therapy) was stable disease (four cycles or 8 weeks), which was observed in $44 \%$ of the evaluable patients. In all ficlatuzumab-treated patients, serum HGF levels were increased compared with baseline, likely due to the stabilization of HGF upon complex formation with ficlatuzumab. ${ }^{52} \mathrm{~A}$ phase $\mathrm{Ib}$ trial evaluated combination treatment with ficlatuzumab and gefitinib in 15 molecularly unselected Asian NSCLC patients. At the $20 \mathrm{mg} \mathrm{kg}^{-1}$ dose, five patients had a partial response and four had stable disease after 12 weeks of treatment. ${ }^{53}$ The half-life of single-agent ficlatuzumab was approximately 7-10 days. ${ }^{54,55}$ A multicenter, open-label, randomized phase II study evaluated combination treatment with ficlatuzumab and gefitinib versus gefitinib alone in Asian patients with lung adenocarcinoma not selected for EGFR mutational status. In a subgroup of patients with EGFR mutations and low cMET expression, patients treated with ficlatuzumab combined with gefitinib showed an improved objective response rate (41\% vs $22 \%$ ) and median progression-free survival (11 vs 5.5 months). However, in the overall population no significant difference was observed in response rate (40 vs $43 \%$ in the gefitinib arm vs combination arm, respectively) or progression-free survival (4.7 months vs 5.6 months in the gefitinib arm vs combination arm, respectively). ${ }^{54,56}$ Results of a phase II study in a pulmonary adenocarcinoma population enriched for activating EGFR mutations showed that combination treatment with ficlatuzumab and gefitinib did not improve clinical outcomes compared to gefitinib monotherapy. Patients who are classified as VeriStrat-poor may benefit from the addition of ficlatuzumab. ${ }^{57}$ However, a recent phase II study (NCT02318368) comparing first-line treatment with ficlatuzumab plus erlotinib versus erlotinib monotherapy in VeriStrat-poor patients with EGFR-mutated NSCLC was discontinued because of a high discontinuation rate in the combination treatment arm.

\section{HuL2G7 (TAK-701)}

HuL2G7 is a humanized antibody shown to overcome gefitinib resistance in EGFR-mutated human NSCLC cell lines. ${ }^{58}$ A phase I study conducted in patients with advanced solid malignancies showed that HuL2G7 had no specific dose-limiting toxicities, but adverse events included cough, abdominal pain, constipation and fatigue. ${ }^{59}$ Further clinical trials have not been pursued.

\section{YYB-101}

YYB-101 is a humanized rabbit anti-HGF antibody. The preclinical development of this drug is described by Kim et al. in this issue. YYB-101 binds to the HGF $\alpha$-chain, where the first high-affinity binding with cMET takes place (unpublished data). This drug inhibits cMET activation and cell scattering in vitro and tumor growth in several xenograft 
mouse models. ${ }^{60,61} \mathrm{~A}$ phase I clinical study in patients with advanced solid tumors is ongoing (NCT02499224).

\section{ANTIBODY MIMETIC ENGINEERED PROTEIN MP0250}

MP0250 is a designed ankyrin repeat protein that neutralizes both HGF and vascular endothelial growth factor. The ability to bind to human serum albumin extends the plasma half-life of MP0250 to 12 days. $^{62}$ As monotherapy and in combination with bortezomib, MP0250 inhibits myeloma cell migration, invasion and bone destruction in an orthotopic mouse model of multiple myeloma. ${ }^{63}$ Phase I interim results showed that MP0250 monotherapy was well tolerated, and a maximum tolerated dose had not been reached. Stable disease for 10 months was observed in one patient with a head and neck tumor and for 8 months in a patient with cervical adenocarcinoma. ${ }^{64}$ Based on preclinical and phase I study results, a phase II study is planned to evaluate MP0250 combined with bortezomib and dexamethasone in patients with multiple myeloma who have failed standard therapies.

\section{COMPETITIVE ANALOGS OF HGF}

\section{NK4}

NK4 is a synthetic molecule that consists of the N-terminal domain and four Kringle domains of HGF and lacks 16 amino acids from the HGF C-terminus. This drug binds cMET without activating signal transduction and exerts anti-growth, anti-metastasis and anti-angiogenic actions in various cancer animal models. ${ }^{19}$ In preclinical studies, adenoviruses expressing the NK4 gene have demonstrated antitumor effects in numerous types of tumors including mesothelioma and pancreatic cancer. ${ }^{65,66} \mathrm{~A}$ phase I clinical study of gene therapy using the NK4-expressing adenoviral vector in patients with mesothelioma is ongoing. ${ }^{67}$

\section{Other HGF mimic molecules}

Uncleavable pro-HGF, generated by introducing a point mutation at the cleavage site (Arg494Gln), inhibits HGF-mediated cMET activation in vitro and local or systemic expression of pro-HGF suppresses tumor growth and prevents metastatic dissemination in mice. ${ }^{19}$ Mutations near the pocket region of the HGF protein (D672N, V495G, V495A, G498I and G498V) inhibit cMET activation because the N-terminal active pocket present in the HGF $\beta$-chain is required to stabilize interactions with cMET. Mutated HGF proteins suppress cMET phosphorylation and cancer cell migration in vitro. ${ }^{68}$

\section{CONCLUSION}

The HGF-cMET pathway is a promising target for cancer therapy. A number of antibodies and engineered-proteins targeting HGF or cMET have been shown to be safe in clinical trials. However, none have demonstrated a significant clinical benefit to patients, with the exception of ficlatuzumab, which was shown to provide benefit to patients classified as VeriStrat-poor in a retrospective analysis of a failed clinical trial. Thus, better biomarkers may be needed for patient selection, or different clinical indications considered for future trials.

\section{CONFLICT OF INTEREST}

The authors declare no conflict of interest.

\section{ACKNOWLEDGEMENTS}

This study was supported by the National OncoVenture Program (No. HI11C1191) and research grants from the National Cancer Center Grants (NCC0911670 and NCC1111370).

1 Tempest PR, Stratton MR, Cooper CS. Structure of the met protein and variation of met protein kinase activity among human tumour cell lines. $\mathrm{Br} \mathrm{J}$ Cancer 1988; 58: 3-7.

2 Donate LE, Srinivasan N, Sowdhamini R, Gherardi E, Blundell TL, Aparicio S. Molecular evolution and domain structure of plasminogenrelated growth factors (HGF/SF and HGF1/MSP). Protein Sci 1994; 3: 2378-2394.

3 Kirchhofer D, Yao X, Peek M, Eigenbrot C, Lipari MT, Billeci KL et al. Structural and functional basis of the serine protease-like hepatocyte growth factor beta-chain in Met binding and signaling. J Biol Chem 2004; 279: 39915-39924.

4 Birchmeier C, Birchmeier W, Gherardi E, Vande Woude GF. Met, metastasis, motility and more. Nat Rev Mol Cell Biol 2003; 4: 915-925.

5 Blumenschein GR, Mills GB, Gonzalez-Angulo AM. Targeting the hepatocyte growth factor-cMET axis in cancer therapy. J Clin Oncol 2012; 30: 3287-3296.

6 Sattler M, Reddy MM, Hasina R, Gangadhar T, Salgia R. The role of the c-Met pathway in lung cancer and the potential for targeted therapy. Ther Adv Med Oncol 2011; 3: 171-184.

7 Li G, Schaider H, Satyamoorthy K, Hanakawa Y, Hashimoto K, Herlyn M. Downregulation of E-cadherin and Desmoglein 1 by autocrine hepatocyte growth factor during melanoma development. Oncogene 2001; 20: 8125-8135.

8 Koochekpour S, Jeffers M, Rulong S, Taylor G, Klineberg E, Hudson EA et al. Met and hepatocyte growth factor/scatter factor expression in human gliomas. Cancer Res 1997; 57: 5391-5398.

9 Jo M, Stolz DB, Esplen JE, Dorko K, Michalopoulos GK, Strom SC. Cross-talk between epidermal growth factor receptor and c-Met signal pathways in transformed cells. J Biol Chem 2000; 275: 8806-8811.

10 Tang Z, Du R, Jiang S, Wu C, Barkauskas DS, Richey J et al. Dual MET-EGFR combinatorial inhibition against T790M-EGFR-mediated erlotinib-resistant lung cancer. Br J Cancer 2008; 99: 911-922.

11 Bean J, Brennan C, Shih J-Y, Riely G, Viale A, Wang L et al. MET amplification occurs with or without T790M mutations in EGFR mutant lung tumors with acquired resistance to gefitinib or erlotinib. Proc Natl Acad Sci USA 2007; 104: 20932-20937.

12 Seidel C, Børset M, Turesson I, Abildgaard N, Sundan A, Waage A. Elevated serum concentrations of hepatocyte growth factor in patients with multiple myeloma. The Nordic Myeloma Study Group. Blood 1998; 91: 806-812.

13 Sheen-Chen S-M, Liu Y-W, Eng H-L, Chou F-F. Serum levels of hepatocyte growth factor in patients with breast cancer. Cancer Epidemiol Biomarkers Prev 2005; 14: 715-717.

14 Xie Q, Bradley R, Kang L, Koeman J, Ascierto ML, Worschech A et al. Hepatocyte growth factor (HGF) autocrine activation predicts sensitivity to MET inhibition in glioblastoma. Proc Natl Acad Sci USA 2012; 109: 570-575.

15 Oda Y, Sakamoto A, Saito T, Kinukawa N, Iwamoto Y, Tsuneyoshi M. Expression of hepatocyte growth factor (HGF)/scatter factor and its receptor c-MET correlates with poor prognosis in synovial sarcoma. Hum Pathol 2000; 31: 185-192.

16 Christensen JG, Burrows J, Salgia R. c-Met as a target for human cancer and characterization of inhibitors for therapeutic intervention. Cancer Lett 2005; 225: 1-26.

17 Nakamura M, Ono YJ, Kanemura M, Tanaka T, Hayashi M, Terai Y et al. Hepatocyte growth factor secreted by ovarian cancer cells stimulates peritoneal implantation via the mesothelial-mesenchymal transition of the peritoneum. Gynecol Oncol 2015; 139: 345-354. 
18 Zeng Z-S, Weiser MR, Kuntz E, Chen C-T, Khan SA, Forslund A et al. c-Met gene amplification is associated with advanced stage colorectal cancer and liver metastases. Cancer Lett 2008; 265: 258-269.

19 Mizuno S, Nakamura T. HGF-MET cascade, a key target for inhibiting cancer metastasis: the impact of NK4 discovery on cancer biology and therapeutics. IJMS 2013; 14: 888-919.

20 Zhang $\mathrm{Y}$, Jain R, Zhu M. Recent progress and advances in HGF/METtargeted therapeutic agents for cancer treatment. Biomedicines 2015; 3: 149-181.

21 Comoglio PM, Giordano S, Trusolino L. Drug development of MET inhibitors: targeting oncogene addiction and expedience. Nat Rev Drug Discov 2008; 7: 504-516.

22 Merchant M, Ma X, Maun HR, Zheng Z, Peng J, Romero M et al. Monovalent antibody design and mechanism of action of onartuzumab, a MET antagonist with anti-tumor activity as a therapeutic agent. Proc NatI Acad Sci USA 2013; 110: E2987-E2996.

23 Martens T, Schmidt N-O, Eckerich C, Fillbrandt R, Merchant M, Schwall R et al. A novel one-armed anti-c-Met antibody inhibits glioblastoma growth in vivo. Clin Cancer Res 2006; 12: 6144-6152.

24 Jin H, Yang R, Zheng Z, Romero M, Ross J, Bou-Reslan H et al. MetMAb, the one-armed 5D5 anti-c-Met antibody, inhibits orthotopic pancreatic tumor growth and improves survival. Cancer Res 2008; 68: 4360-4368.

25 Salgia R, Patel P, Bothos J, Yu W, Eppler S, Hegde P et al. Phase I doseescalation study of onartuzumab as a single agent and in combination with bevacizumab in patients with advanced solid malignancies. Clin Cancer Res 2014; 20: 1666-1675.

26 Spigel DR, Ervin TJ, Ramlau RA, Daniel DB, Goldschmidt JH, Blumenschein GR et al. Randomized phase II trial of Onartuzumab in combination with erlotinib in patients with advanced non-small-cell lung cancer. J Clin Oncol 2013; 31: 4105-4114.

27 Koeppen H, Yu W, Zha J, Pandita A, Penuel E, Rangell L et al. Biomarker analyses from a placebo-controlled phase II study evaluating Erlotinib + Onartuzumab in advanced non-small cell lung cancer: MET expression levels are predictive of patient benefit. Clin Cancer Res 2014; 20: 4488-4498.

28 Diéras V, Campone M, Yardley DA, Romieu G, Valero V, Isakoff SJ et al. Randomized, phase II, placebo-controlled trial of onartuzumab and/or bevacizumab in combination with weekly paclitaxel in patients with metastatic triple-negative breast cancer. Ann Oncol 2015; 26: mdv263-1910.

29 Charakidis M, Boyer M. Targeting MET and EGFR in NSCLC-what can we learn from the recently reported phase III trial of onartuzumab in combination with erlotinib in advanced non-small cell lung cancer? Trans/ Lung Cancer Res 2014; 3: 395-396.

30 Liu L, Zeng W, Wortinger MA, Yan SB, Cornwell P, Peek VL et al. LY2875358, a neutralizing and internalizing anti-MET bivalent antibody, inhibits HGF-dependent and HGF-independent MET activation and tumor growth. Clin Cancer Res 2014; 20: 6059-6070.

31 Rosen LS, Goldman JW, Algazi AP, Turner PK, Moser B, Hu T et al. A first-in-human phase I study of a bivalent MET antibody, Emibetuzumab (LY2875358), as monotherapy and in combination with erlotinib in advanced cancer. Clin Cancer Res (e-pub ahead of print 3 February 2017; doi:10.1158/1078-0432.CCR-16-1418).

32 Liu L, Zeng W, Chedid M, Zeng Y, Tschang S-H, Tian Y et al. Abstract 873: A novel MET-EGFR bispecific antibody LY3164530 shows advantage over combining MET and EGFR antibodies in tumor inhibition and overcome resistance. Cancer Res 2016; 76: 873-873.

33 Moores SL, Chiu ML, Bushey BS, Chevalier K, Luistro L, Dorn K et al. A novel bispecific antibody targeting EGFR and cMet is effective against EGFR inhibitor-resistant lung tumors. Cancer Res 2016; 76: 3942-3953.

34 Labrijn AF, Meesters JI, Priem P, de Jong RN, van den Bremer ETJ, van Kampen MD et al. Controlled Fab-arm exchange for the generation of stable bispecific IgG1. Nat Protoc 2014; 9: 2450-2463.

35 Jarantow SW, Bushey BS, Pardinas JR, Boakye K, Lacy ER, Sanders R et al. Impact of cell-surface antigen expression on target engagement and function of an epidermal growth factor receptor $\times$ C-MET bispecific antibody. J Biol Chem 2015; 290: 24689-24704.

36 Grugan KD, Dorn K, Jarantow SW, Bushey BS, Pardinas JR, Laquerre S et al. Fc-mediated activity of EGFR $\times$ c-Met bispecific antibody JNJ-61186372 enhanced killing of lung cancer cells. MAbs 2016; 9: 114-126.

37 Moores SL, Chiu M, Bushey B, Chevalier K, Haytko P, Neijssen J et al. Abstract DDT01-03: discovery and preclinical pharmacology of JNJ-61186372: a novel bispecific antibody targeting EGFR and CMET. Cancer Res 2014; 74 (Suppl 19).
38 Lee JM, Kim B, Lee SB, Jeong Y, Oh YM, Song Y-J et al. Cbl-independent degradation of Met: ways to avoid agonism of bivalent Met-targeting antibody. Oncogene 2014; 33: 34-43.

39 Lee B-S, Kang S, Kim K-A, Song Y-J, Cheong KH, Cha H-Y et al. Met degradation by SAIT301, a Met monoclonal antibody, reduces the invasion and migration of nasopharyngeal cancer cells via inhibition of EGR-1 expression. Cell Death Dis 2014; 5: e1159.

40 Kang SK, Kim JM, Lee WS, Kwon WS, Kim TS, Shim S-H et al. Abstract 661: Increasing sensitivity of SAIT301, a specific monoclonal antibody of c-Met, with paclitaxel combination in c-Met positive gastric cancer. Cancer Res 2015; 75: 661-661.

41 Wang J, Goetsch L, Tucker L, Zhang Q, Gonzalez A, Vaidya KS et al. Anti-c-Met monoclonal antibody ABT-700 breaks oncogene addiction in tumors with MET amplification. BMC Cancer 2016; 16: 1-14.

42 Hultberg A, Morello V, Huyghe L, De Jonge N, Blanchetot C, Hanssens V et al. Depleting MET-expressing tumor cells by ADCC provides a therapeutic advantage over inhibiting HGF/MET signaling. Cancer Res 2015; 75: 3373-3383.

43 Hanssens V, De Jonge N, Hultberg A, Borg C, Michieli P, Dreier T et al. The clinical potential of ARGX-111, an afucosylated anti-MET antibody, in hematological malignancies and suppression of metastasis. Ann Oncol 2015; 26 (Suppl 2): ii31.

44 Petrelli A, Circosta P, Granziero L, Mazzone M, Pisacane A, Fenoglio S et al. Ab-induced ectodomain shedding mediates hepatocyte growth factor receptor down-regulation and hampers biological activity. Proc Natl Acad Sci USA 2006; 103: 5090-5095.

45 Pacchiana G, Chiriaco C, Stella MC, Petronzelli F, De Santis R, Galluzzo M et al. Monovalency unleashes the full therapeutic potential of the DN-30 anti-Met antibody. J Biol Chem 2010; 285: 36149-36157.

46 Vigna E, Pacchiana G, Chiriaco C, Cignetto S, Fontani L, Michieli P et al. Targeted therapy by gene transfer of a monovalent antibody fragment against the Met oncogenic receptor. J Mol Med 2014; 92: 65-76.

47 Vigna E, Comoglio PM. Targeting the oncogenic Met receptor by antibodies and gene therapy. Oncogene 2015; 34: 1883-1889.

48 Burgess TL, Sun J, Meyer S, Tsuruda TS, Sun J, Elliott G et al. Biochemical characterization of AMG 102: a neutralizing, fully human monoclonal antibody to human and nonhuman primate hepatocyte growth factor. $\mathrm{Mol}$ Cancer Ther 2010; 9: 400-409.

49 Gordon MS, Sweeney CS, Mendelson DS, Eckhardt SG, Anderson A, Beaupre DM et al. Safety, pharmacokinetics, and pharmacodynamics of AMG 102, a fully human hepatocyte growth factor-neutralizing monoclonal antibody, in a first-in-human study of patients with advanced solid tumors. Clin Cancer Res 2010; 16: 699-710.

50 Iveson T, Donehower RC, Davidenko I, Tjulandin S, Deptala A, Harrison M et al. Rilotumumab in combination with epirubicin, cisplatin, and capecitabine as first-line treatment for gastric or oesophagogastric junction adenocarcinoma: an open-label, dose de-escalation phase $1 \mathrm{~b}$ study and a double-blind, randomised phase 2 study. Lancet Oncol 2014; 15: 1007-1018.

51 Cunningham D, Tebbutt NC, Davidenko I, Murad AM, Al-Batran S-E, IIson $\mathrm{DH}$ et al. Phase III, randomized, double-blind, multicenter, placebo (P)-controlled trial of rilotumumab (R) plus epirubicin, cisplatin and capecitabine (ECX) as first-line therapy in patients (pts) with advanced MET-positive (pos) gastric or gastroesophageal junction (G/GEJ) cancer: RILOMET-1 study. J Clin Oncol 2015; 33 (Suppl 15).

52 Patnaik A, Weiss GJ, Papadopoulos KP, Hofmeister CC, Tibes R, Tolcher A et al. Phase I ficlatuzumab monotherapy or with erlotinib for refractory advanced solid tumours and multiple myeloma. Br J Cancer 2014; 111: 272-280.

53 Tan E, Park K, Lim WT, Ahn M, Ng QS, Ahn JS et al. Phase Ib study of ficlatuzumab (formerly AV-299), an anti-hepatocyte growth factor (HGF) monoclonal antibody (MAb) in combination with gefitinib (G) in Asian patients (pts) with NSCLC. J Clin Oncol 2016; 29: 7571.

54 D'Arcangelo M, Cappuzzo F. Focus on the potential role of ficlatuzumab in the treatment of non-small cell lung cancer. Biologics 2013; 7: 61-68.

55 Elez E, Tabernero J, Prudkin L, Agarwal S, Han M, Credi M et al. Abstract 443PD: pharmacodynamic-pharmacokinetic study of ficlatuzumab, a monoclonal antibody directed to the hepatocyte growth factor (HGF), in patients with advanced solid tumors who have live metastases. Ann Oncol 2012; 23: ix154.

56 Mok TSK, Park K, Geater SL, Agarwal S, Han M, Credi M et al. Abstract 1198 P: a randomized phase 2 study with exploratory biomarker analysis of ficlatuzumab, a humanized hepatocyte growth factor (HGF) inhibitory monoclonal antibody, in combination with gefitinib versus gefitinib 
alone in Asian patients with lung adenocarcinoma. Ann Oncol 2015; 23: ix391.

57 Mok TSK, Geater SL, Su W-C, Tan E-H, JC-H Yang, Chang G-C et al. A randomized phase 2 study comparing the combination of ficlatuzumab and gefitinib with gefitinib alone in Asian patients with advanced stage pulmonary adenocarcinoma. J Thorac Oncol 2016; 11: 1736-1744.

58 Okamoto W, Okamoto I, Tanaka K, Hatashita E, Yamada Y, Kuwata K et al. TAK-701, a humanized monoclonal antibody to hepatocyte growth factor, reverses gefitinib resistance induced by tumor-derived HGF in non-small cell lung cancer with an EGFR mutation. Mol Cancer Ther 2010; 9: 2785-2792.

59 Jones SF, Cohen RB, Bendell JC, Denlinger CS, Harvey RD, Parasuraman S et al. Safety, tolerability, and pharmacokinetics of TAK-701, a humanized anti-hepatocyte growth factor (HGF) monoclonal antibody, in patients with advanced nonhematologic malignancies: First-in-human phase I dose-escalation study. J Clin Oncol 2010; 28: 3081.

60 Kim K, Hur Y, Ryu E-K, Rhim J-H, Choi CY, Baek C-M et al. A neutralizable epitope is induced on HGF upon its interaction with its receptor cMet. Biochem Biophys Res Commun 2007; 354: 115-121.

61 Woo JK, Kang J-H, Kim B, Park BH, Shin K-J, Song S-W et al. Humanized anti-hepatocyte growth factor (HGF) antibody suppresses innate irinotecan (CPT-11) resistance induced by fibroblast-derived HGF. Oncotarget 2015; 6: 24047-24060.

62 Middleton MR, Azaro A, Kumar S, Niedermann P, Rodón J, Herbschleb KH et al. Interim results from the completed first-in-human phase I dose escalation study evaluating MP0250, a multi-DARPin blocking HGF and VEGF, in patients with advanced solid tumors. Ann Oncol 2016; 27: 361PD.

63 Fiedler U, Cornelius A, Ekawardhani S, Dawson KM, Gilboy P, Stumpp MT et al. Potency of bortezomib in combination with MP0250, a bispecific VEGF- and HGF-targeting darpin, in a preclinical multiple myeloma model. J Clin Oncol 2014; 32: e19574.
64 Rodon J, Omlin A, Herbschleb KH, Garcia-Corbacho J, Steiner J, Dolado I et al. Abstract B25: first-in-human Phase I study to evaluate MP0250, a DARPin blocking HGF and VEGF, in patients with advanced solid tumors. Mol Cancer Ther 2016; 14: B25-B25.

65 Suzuki Y, Sakai K, Ueki J, Xu Q, Nakamura T, Shimada H et al. Inhibition of Met/HGF receptor and angiogenesis by NK4 leads to suppression of tumor growth and migration in malignant pleural mesothelioma. Int $\mathrm{J}$ Cancer 2010; 127: 1948-1957.

66 Murakami M, Nagai E, Mizumoto K, Saimura M, Ohuchida K, Inadome N et al. Suppression of metastasis of human pancreatic cancer to the liver by transportal injection of recombinant adenoviral NK4 in nude mice. Int J Cancer 2005; 117: 160-165.

67 Suzuki T, Tada Y, West J, Tatsumi K, Tagawa M, Hiroshima K et al. Gene therapy using NK4 expressing adenoviral vector for unresectable malignant pleural mesothelioma. Chest 2016; 149: A327-A327.

68 Kirchhofer D, Lipari MT, Santell L, Billeci KL, Maun HR, Sandoval WN et al. Utilizing the activation mechanism of serine proteases to engineer hepatocyte growth factor into a Met antagonist. Proc Natl Acad Sci USA 2007; 104: 5306-5311.

(c) (1) This work is licensed under a Creative Commons Attribution 4.0 International License. The images or other third party material in this article are included in the article's Creative Commons license, unless indicated otherwise in the credit line; if the material is not included under the Creative Commons license, users will need to obtain permission from the license holder to reproduce the material. To view a copy of this license, visit http:// creativecommons.org/licenses/by/4.0/ 